\title{
Microsatellite analysis of Alpine grape cultivars (Vitis vinifera L.): alleged descendants of Pliny the Elder's Raetica are genetically related
}

\author{
José F. Vouillamoz • Anna Schneider • \\ M. Stella Grando
}

Received: 27 January 2006/ Accepted: 19 June 2006/Published online: 11 November 2006

(C) Springer Science+Business Media B.V. 2006

\begin{abstract}
According to Pliny the Elder and other Greco-Roman geoponics, Raetica was a famous white grape as well as a white wine produced in Raetia, a Province of the Roman Empire. Does Raetica grape have modern descendants? Etymologically and geographically, the white 'Rèze' from Valais (Switzerland) would be the best candidate. Using available microsatellite data, we searched for relatives of 'Rèze' in our database containing over 1,700 genotypes of grape cultivars from all over the world. Twelve cultivars showing putative first-degree (parentoffspring or full-siblings) or second-degree (grandparent-grandoffspring, uncle-nephew or half-siblings) relationships with 'Rèze' were then analysed at 60 microsatellite markers. Calculation of allele sharing and likelihood ratios between competing relationship categories revealed that
\end{abstract}

J. F. Vouillamoz · M. S. Grando

Istituto Agrario, Laboratory of Molecular Genetics,

Via Mach 1, 38010 San Michele all'Adige, TN, Italy

\section{A. Schneider}

CNR, Istituto di Virologia Vegetale, Unità

Viticoltura, Torino, Italy

J. F. Vouillamoz $(\varangle)$

National Centre of Competence in Research "Plant

Survival", University of Neuchâtel, Rue Emile

Argand 11, CH-2007 Neuchâtel, Switzerland

e-mail: jose.vouillamoz@unine.ch four cultivars had parent-offspring relationship with 'Rèze': 'Cascarolo Bianco' (Piedmont, Italy), 'Arvine Grande' (Valais, Switzerland), 'Groppello di Revò' and 'Nosiola' (Trentino, Italy). Given that some of these are also said to be Raetica descendants, we may well be on the tracks of Pliny the Elder's Raetica grape. However, there is no evidence about the identity of Raetica. Analysis of ancient DNA of grape pips excavated from archaeological sites of the Roman times might provide key information. Our first attempts were unsuccessful, but analysis of additional samples and optimisation of the method could provide groundbreaking results about the identity of the grapes cultivated in classical antiquity.

Keywords Grape cultivar - Microsatellite · Parentage $\cdot$ Likelihood ratios $\cdot$ Vitis vinifera

\section{Introduction}

Raetica (or Rhaetica) was mentioned by the Greco-Roman authors as one of the most widespread white wine and white grape (Vitis vinifera L.) in Raetia, a Province of the Roman Empire corresponding to modern Graubünden (Switzerland), Vorarlberg (western Austria), Tirol (Austria and northern Italy) and part of Lombardy (northern Italy). Cato (234-149 BC) provided in De Re Rustica the first written mention of Raetica 
wine. Virgil (70-19 BC) stated in Georgica II that only Falernum, the renowned wine of Rome, surpassed Raetica. At the same time, the Greek Strabo considered in Geographika the wine of the Reti, the inhabitants of Raetia, as good as the most famous wines of Rome. In Re Medica, Celsi suggested to drink warm Raetica against sterility, as well as other resinated wines such as Allobrogica (Buchi 1996). This property was probably related to the good fertility of the Raetica grape, as mentioned by Columella (1st century AD) in $D e$ Re Rustica III (Tchernia 1986). Pliny the Elder (23-79 AD) provided the first mention of Raetica as a grape. In his Historiae Naturalis XIV, he considered the region of Verona as the homeland of Raetica. Yet, he did distinguish a Raetica from the Maritime Alps, producing a poor wine, from a Raetica growing in the territory of Verona, producing one of the best wines of that time.

Today, it is problematical to pinpoint which modern varieties might be descendants of Raetica. The Austrian 'Veltliner', supposedly originating from Valtelline Valley (Lombardy, northern Italy), is a putative candidate (Buchi 1996). Indeed, the Swiss botanist Bauhin (1650) used the name Veltolinas for Uvae Rheticae, a group of grapes cultivated in Valtelline. In addition, Jean Hardouin, an erudite Jesuit who edited Pliny's Historiae Naturalis in 1685, annotated that Raetica grapes were still growing in Valtelline and were remarkable for their excellence (Crane 2005). However, this hypothesis is doubtful because today the name 'Veltliner' is used for several distinct and partially unrelated grape cultivars (Sefc et al. 1998) and because none of them has ever been mentioned in Valtelline. The most serious candidate as a descendant of Raetica is 'Rèze', a white grape cultivar confined to Valais (Switzerland), an Alpine region bordering the former land of the Raeti. Etymologically, Aebischer (1937) hypothesized that the name Raetica has outlived in the modern 'Rèze' that was already mentioned in 1313. Furthermore, 'Rèze' is considered the sole modern etymological relict of the Raetica grape (André and Levadoux 1964). Nevertheless, Berget (1903) suggested that 'Rèze' was a descendant of 'Prié', a white cultivar from the neighbouring Aosta Valley (Italy), and Desfayes (2002) proposed that the name 'Rèze' derived from Retz region in Austria rather than Raeti or Raetica.

In the present study, we used microsatellites, the undisputed markers of choice for grape identification and parentage analysis (Sefc et al. 2001), to follow the tracks of Raetica by searching for possible parents and relatives of 'Rèze' in our database. This database contains microsatellite data of more than 1,700 grape cultivars from all over the world, with particular emphasis on traditional cultivars from the land of the Raeti. Using a probabilistic approach recently applied successfully for the first time to grape cultivars (Vouillamoz and Grando in press), we present here several unexpected parent-offspring pairs and other genetic relationships with 'Rèze'.

\section{Materials and methods}

Plant material and microsatellite analysis

In order to select the cultivars to be analysed, we compared at every already available microsatellite markers the genotype of 'Rèze' (sampled from RAC: the collection at Agroscope RAC Changins, Centre Viticole du Caudoz, Pully, Switzerland) to the genotypes of more than 1,700 grape cultivars from all over the world, put together and standardized from different sources: SSR database of the University of California, Davis (Carole Meredith, personal communication); Grape Microsatellite Collection, IASMA, Italy $^{1}$; Greek Vitis Database, University of Crete, Heraklion, Greece ${ }^{2}$; Bulgarian Grape nSSR Database $^{3}$; various references in literature; personal unpublished data. In particular, we thoroughly investigated 151 traditional grape cultivars (Table 1) from the land of the Raeti and surrounding areas (Austria, Germany, northern Italy and Switzerland) for possible genetic relationship with 'Rèze'. Using the computer program LOCI (A. Schneider and P. Bussa, CNR-IVV unpublished) to detect pairs sharing at

\footnotetext{
$\overline{{ }^{1} \mathrm{http}: / / w w w}$. ismaa.it/areabioav/gmc.html

${ }^{2}$ http://www.biology.uoc.gr/gvd/

3 http://www.bulgenom.abi.bg/Grape \%20nSSR \%20Database.html
} 
Table 1 Grapevine cultivars included in this study

\begin{tabular}{|c|c|c|c|}
\hline Austria & Northern Italy & Northern Italy & Northern Italy \\
\hline Blauer Portugieser & Lombardy & Piedmont & Veneto \\
\hline Brauner Veltliner & Croatina & Neiret & Cabrusina \\
\hline Frühroter Veltliner & Groppello di S. Stefano & Neretta Cuneese & Corvina Veronese \\
\hline Grüner Veltliner & Groppellone & Neretto di Marengo & Corvinone \\
\hline Österreichisch wei $\beta$ & Moscato di Scanzo & Neretto Duro & Dindarella \\
\hline Rotgipfler & Piedmont & Neretto Gentile & Durella \\
\hline St. Laurent & Arneis & Pelaverga & Garganega \\
\hline Zierfandler Rot & Avanà & Pignolo Spano & Mollinara \\
\hline Germany & Avarengo & Quagliano & Oseleta \\
\hline Affenthaler & Baratuciat & Rastajola & Pelara \\
\hline Elbling & Barbacarlo & Ruché & Raboso del Piave \\
\hline Hansen Rot & Barbassese & Tadone & Rondinella \\
\hline Limberger & Barbera & Timorasso & Rosetta di Montagna \\
\hline Putzscheere & Barbrassa & Uva Rara & Rossola \\
\hline Riesling & Bian ver & Uvalino & Rossoletta \\
\hline Sylvaner & Blanchet & Varenzasca & Trebbiano di Soave \\
\hline Wildbacher Blau & Bonarda Piemontese & Vespolina & Vespaiola \\
\hline Northern Italy & Bonardina & Zanello & Switzerland \\
\hline Aosta Valley & Brachetto d'Acqui & Northern Italy & Graubünden \\
\hline Bonda & Brunetta di Rivoli & Trentino-Alto Adige & Completer \\
\hline Cornalin d'Aoste & Bubbierasco & Biancaccia & Ticino \\
\hline Crovassa & Buzzetto & Enantio & Bondola \\
\hline Fumin & Carcairone Gravere & Groppello di Revò & Valais \\
\hline Mayolet & Cardin & Lagarino Bianco & Amigne \\
\hline Ner d'Ala & Cascarolo Bianco & Lagrein & Arvine \\
\hline Petit Rouge & Cellerina & Lambrusco Casetta & Arvine Grande \\
\hline Premëtta & Cortese & Marzemino & Cornalin du Valais \\
\hline Prié & Crovin & Montagna & Durize \\
\hline Roussin & Dolcetto & Negrara & Eyholzer Roter \\
\hline Roussin de Morgex & Erbaluce & Nera dei Baisi & Goron \\
\hline Vien de Nus & Freisa & Nosiola & Himbertscha \\
\hline Vuillermin & Grignolino & Schiava Grossa & Lafnetscha \\
\hline Emilia-Romagna & Grisa nera & Schiava Media & Humagne Blanc \\
\hline Albana & Lambrusca di Alessandria & Teroldego & Rèze \\
\hline Lambrusco di Sorbara & Lambrusca Vittona & Valderbara & Zurich \\
\hline Friuli & Lambruschetto & Verdealbara & Hitzkircher \\
\hline Refosco dal Pedunculo Rosso & Luglienga & Vernaccia Trentina & Räuschling Blanc \\
\hline Riesling Italico & Malvasia Bianca & Visentina & \\
\hline Schioppettino & Malvasia Casorzo & Valtellina & \\
\hline Tocai Friulano & Malvasia Nera Lunga & Chiavennasca Bianca & \\
\hline Verduzzo Friulano & Malvasia Schierano & Negrera & \\
\hline Liguria & Moscato Nero d'Acqui & Rossera & \\
\hline Albarola & Nascetta & Rossolino Nero & \\
\hline \multirow[t]{2}{*}{ Bosco } & Nebbiolo & & \\
\hline & Neirera & & \\
\hline
\end{tabular}

A total of 151 traditional cultivars from the ancient land of the Raeti and surrounding areas were selected

least one allele at each locus and the program Microsat (Minch et al. 1995) to calculate pairwise genetic distance (Das, proportion of shared alleles), we isolated the cultivars showing putative relationships with 'Rèze'. For further analysis, we obtained samples of these cultivars from the collections at Agroscope RAC Changins, Centre Viticole du Caudoz, Pully, Switzerland (RAC), at
Istituto Agrario di San Michele all'Adige, Trento, Italy (IASMA) and at Unità di Viticoltura dell'Istituto di Virologia Vegetale, Consiglio Nazionale delle Ricerche, Torino, Italy (CNR-IVV). DNA was extracted with the Qiagen DNEasy Plant Mini Kit and all cultivars were genotyped at 60 microsatellite loci (Table 2), including the six microsatellites chosen as a core set for grape 


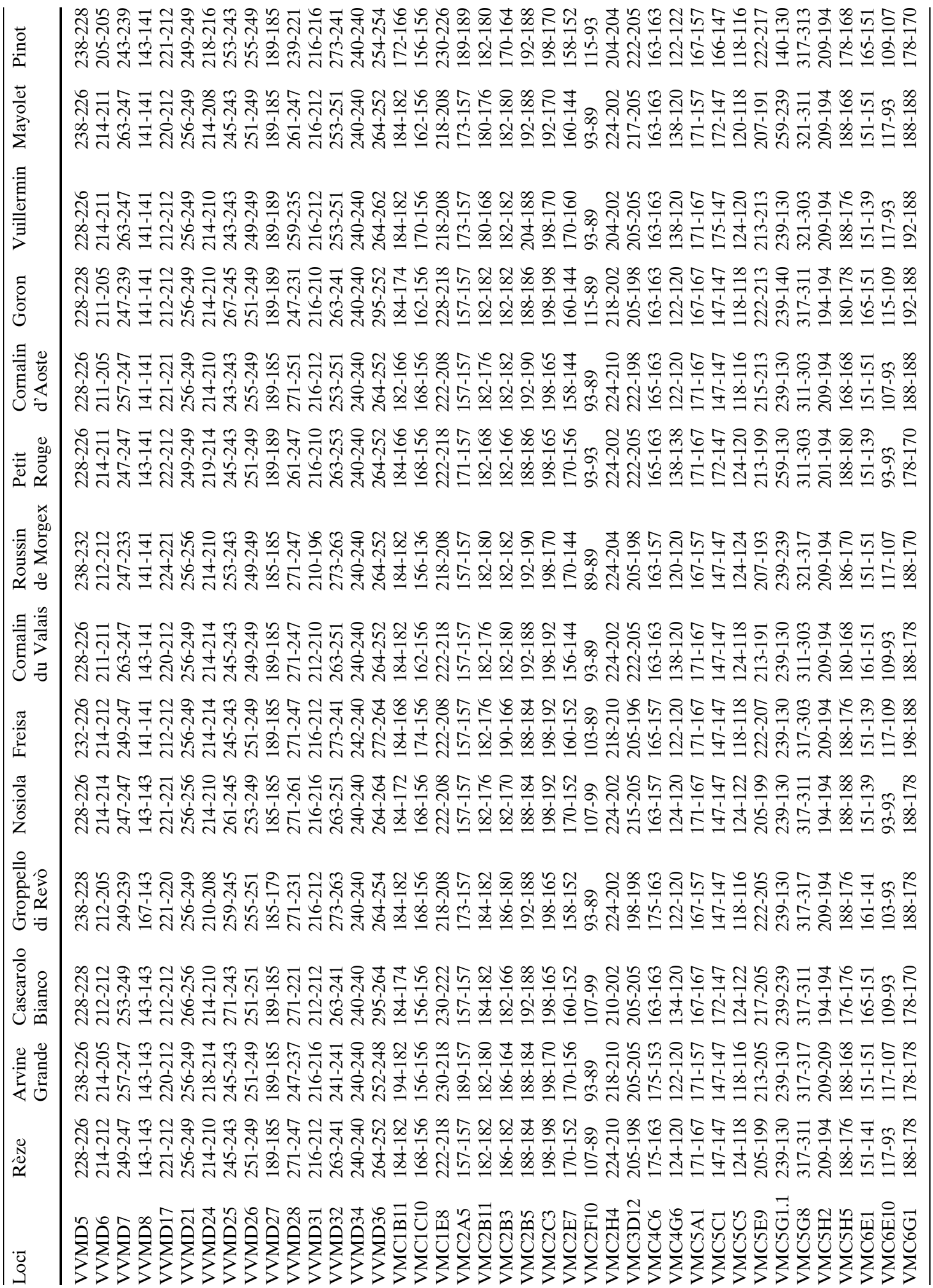




\begin{tabular}{|c|c|}
\hline$\stackrel{\check{0}}{\leftrightarrows}$ & 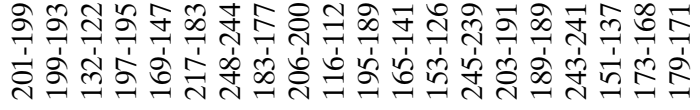 \\
\hline 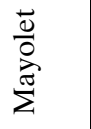 & 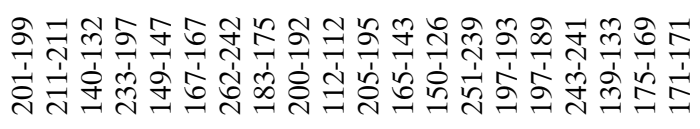 \\
\hline $\begin{array}{l}\text { 苞 } \\
\stackrel{0}{\Xi}\end{array}$ & 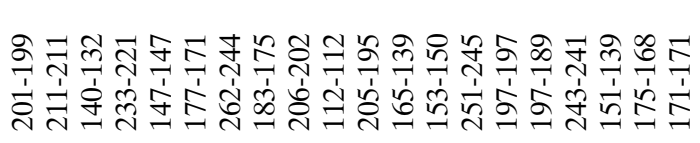 \\
\hline 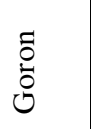 & 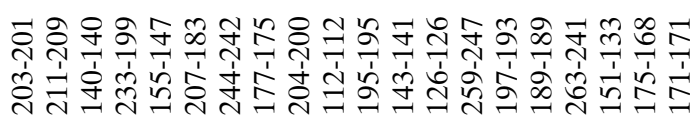 \\
\hline 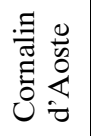 & 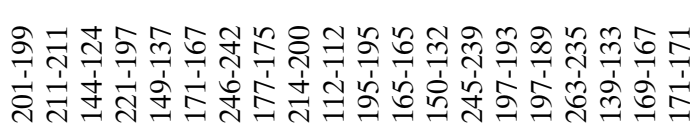 \\
\hline 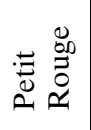 & 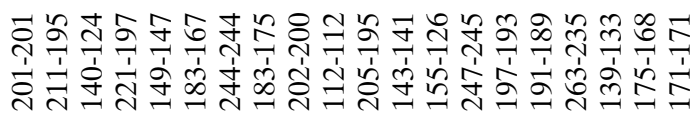 \\
\hline 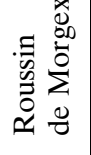 & 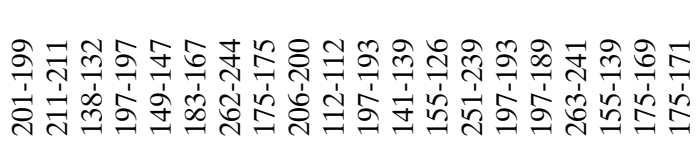 \\
\hline 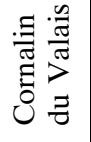 & 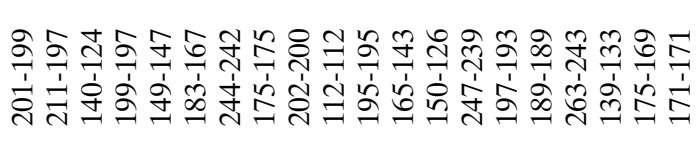 \\
\hline 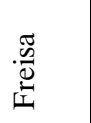 & 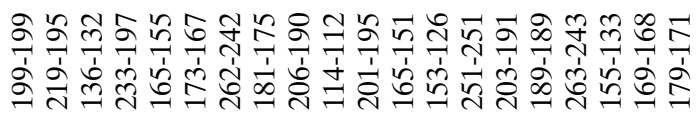 \\
\hline $\begin{array}{l}\frac{\pi}{\circ} \\
\frac{0}{0} \\
0 \\
z\end{array}$ & 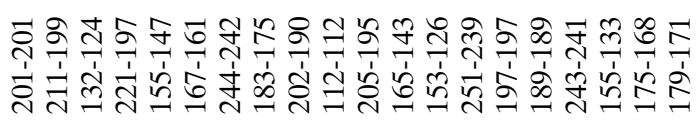 \\
\hline 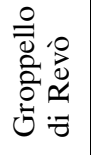 & 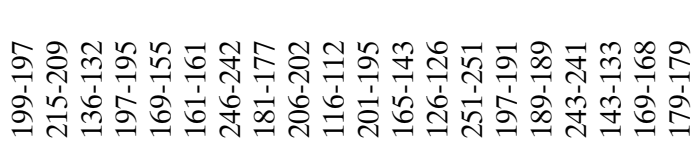 \\
\hline 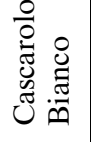 & 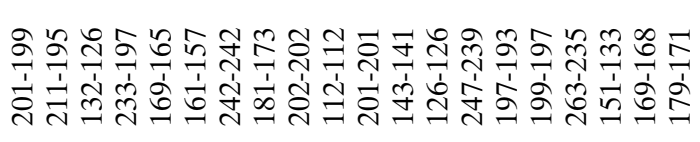 \\
\hline 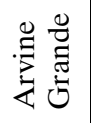 & 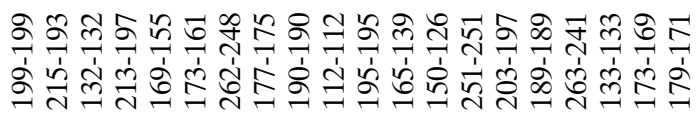 \\
\hline $\begin{array}{l}\stackrel{\sim}{N} \\
\underset{N}{\mathscr{N}}\end{array}$ & 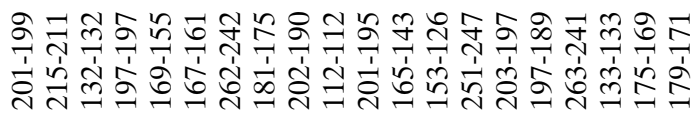 \\
\hline & 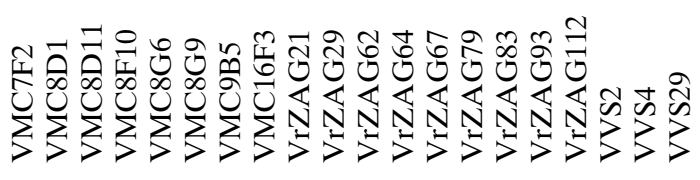 \\
\hline
\end{tabular}


cultivars identification by the GENRES\#81 European research project (This et al. 2004). Primer pairs for most of the VMC microsatellite markers are unpublished (except VMC7F2 in Pellerone et al. 2001) and belong to the Vitis Microsatellite Consortium. Primer pairs for VVMD microsatellites were published in Bowers et al. (1996, 1999); for VrZAG in Sefc et al. (1999); for VVS in Thomas and Scott (1993) and Thomas et al. (1998). The PCR mix was prepared in 10- $\mu \mathrm{l}$ volumes containing $0.2-3.0 \mathrm{ng}$ of template DNA, 2-4 pmol of each forward and reverse primers, $1 \times \mathrm{PCR}$ buffer, $2 \mathrm{mM} \mathrm{MgCl}_{2}$, $0.2 \mathrm{mM}$ dNTPs and $0.5 \mathrm{U}$ of HotStarTaq polymerase. Three different fluorescent dyes (6-FAM, HEX and NED) were used to label the forward primers. All PCR reagents were supplied with the Qiagen HotStarTaq DNA polymerase kit, with the exception of dNTPs (Promega). PCR amplifications were performed in Biometra Tgradient Thermocycler with the following conditions for all markers: $15^{\prime}$ at $95^{\circ}$ (HotStarTaq activation step) followed by 35 cycles consisting of $60^{\prime \prime}$ at $94^{\circ} \mathrm{C}$ (denaturation), $30^{\prime \prime}$ at $52^{\circ} \mathrm{C} / 56^{\circ} \mathrm{C}$ (annealing), $90^{\prime \prime}$ at $72^{\circ} \mathrm{C}$ (extension). In the last cycle, extension time at $72^{\circ} \mathrm{C}$ was increased to $10^{\prime}$. Every individual was amplified at least twice to correct possible mistyping or amplification errors. PCR products were size-separated by capillary electrophoresis performed on a genetic analyser (ABI Prism 3100; Applied Biosystems, Inc.) using Performance Optimised Polymer 4 (POP 4, Applied Biosystems, Inc.). Samples were prepared with $9.6 \mu \mathrm{l}$ of deionised Formamide, $0.1 \mu \mathrm{l}$ of GeneScan 500 ROX size standard (Applied Biosystems, Inc.), and $0.3 \mu \mathrm{l}$ of $10 \times$ diluted PCR product. Mixture was heat denaturated $\left(95^{\circ} \mathrm{C}\right.$ for $3^{\prime}$ ) and placed $5^{\prime}$ on ice prior to injection in the ABI 3100. Alleles were then separated at $15,000 \mathrm{~V}$ for approximately $45^{\prime}$ with a running temperature of $60^{\circ} \mathrm{C}$. Resulting data were analysed with Genescan 3.7 (Applied Biosystems, Inc.) for internal standard and fragment size determination. Allelic designations were ascertained using Genotyper 3.7 (Applied Biosystems, Inc.). Relative allele sizes were determined by comparison with known genotypes of standard cultivars. 'Pinot' from the collection at RAC was included in this study as a well-known reference.
Parent-offspring pairs that were confirmed with 60 microsatellites were assessed in the program KINGROUP v. 1.0 (Konovalov et al. 2004) following Goodnight and Queller's (1999) algorithm to reconstruct pedigree relationships with the relative allelic frequencies of 89 cultivars from western Europe (data not shown). For each putative relationship, pairwise likelihood ratios were calculated between the likelihood of a primary hypothesis (e.g. parent-offspring) and the likelihood (through 3,000 simulations) of the next competing relationship category (e.g. full-siblings).

\section{Results and discussion}

According to literature and etymology, 'Rèze' is the best candidate to represent a modern descendant of Raetica. In search for relatives of 'Rèze' that could be putative descendants of Raetica as well, we screened more than 1,700 microsatellite grape genotypes from all over the world with particular emphasis on 151 cultivars (Table 1) from the former land of the Raetian people and surrounding areas (Austria, Germany, northern Italy and Switzerland). Based on Dps (proportion of shared alleles) pairwise genetic distance, we found 12 grape cultivars having Dps values $<0.5$ with respect to 'Rèze' (data not shown) for further analysis: 'Arvine Grande', 'Cornalin du Valais' and 'Goron' from Valais (Switzerland); 'Cornalin d'Aoste', 'Mayolet', 'Petit Rouge', 'Roussin de Morgex' and 'Vuillermin' from Aosta Valley (Italy); 'Cascarolo Bianco' and 'Freisa' from Piedmont (Italy); 'Groppello di Revò' and 'Nosiola' from Trentino (Italy). Unsurprisingly, they all belong to the 151 cultivars selected in former Raetia (Table 1). As we recently showed that at least 57 microsatellite markers are necessary to establish parent-offspring relationships between two cultivars without knowing the other parent (Vouillamoz and Grando in press), 'Rèze' and its putative relatives were subsequently analysed at a total of 60 microsatellite markers (Table 2). Finally, only four cultivars turned out to share at least one allele at each locus with 'Rèze', thus strongly suggesting parent-offspring relationships: 'Cascarolo 


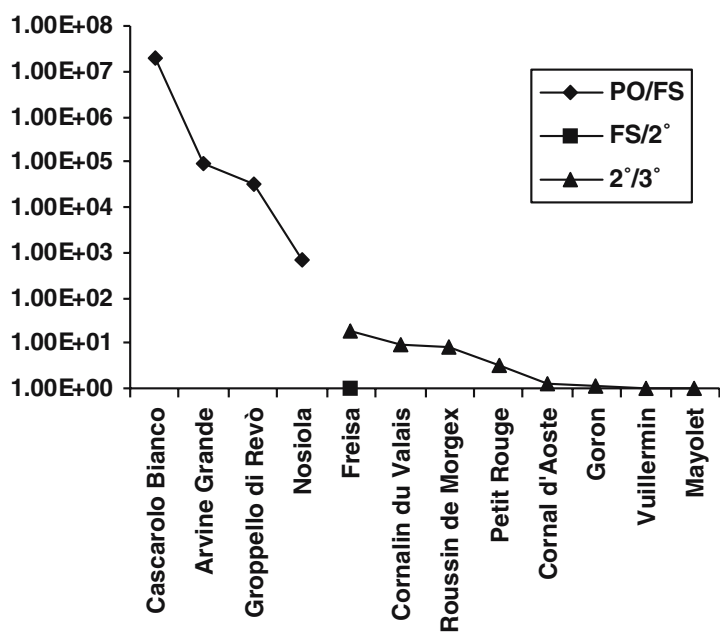

Fig. 1 Likelihood ratios analysis of the relationships with 'Rèze'. The relationship categories considered here are parent-offspring (PO), full-siblings (FS), second-degree $\left(2^{\circ}\right)$ and third-degree $\left(3^{\circ}\right)$ relatives. The ratios (e.g. PO/FS) are calculated between the likelihood of the primary hypothesis (e.g. the cultivar and 'Rèze' are PO) and the likelihood (through simulation) of the next competing relationship category as null hypothesis (e.g. the cultivar and 'Rèze' are FS). As it was almost equally likely that 'Rèze' and 'Freisa' have these genotypes because they are full-siblings instead of second-degree relatives (LRs of FS/ $\left.2^{\circ}=1.06\right)$, we also calculated the LR of $2^{\circ} / 3^{\circ}$ for this pair

Bianco', 'Arvine Grande', 'Groppello di Revò' and 'Nosiola'. These putative parent-offspring pairs were then assessed by likelihood ratio analysis (Fig. 1). The ratios between the likelihood of the primary hypothesis ('Rèze' has parent-offspring relationships with 'Cascarolo Bianco', 'Arvine Grande', 'Groppello di Revò' and 'Nosiola') and the likelihood (through simulation) of the next competing relationship category as null hypothesis (Rèze' has full-siblings relationships with 'Cascarolo Bianco', 'Arvine Grande', 'Groppello di Revò' and 'Nosiola') ranged from $2 \times 10^{7}$ ('Rèze'-'Cascarolo Bianco') to 659 ('Rèze'-'Nosiola'). In other words, it is $2 \times$ $10^{7}$ times more likely that 'Rèze' and 'Cascarolo Bianco' have these genotypes because they are parent-offsprings instead of full-siblings. Ratios were obviously much higher using "unrelated" as null hypothesis (data not shown; e.g. ratios were $1 \times 10^{12}$ and $2 \times 10^{7}$ for 'Rèze'-'Cascarolo Bianco' and 'Rèze'-'Nosiola', respectively). Therefore, all four pairs were significantly supported as parent-offspring. Yet, none of these cultivars had ever been suspected to be related to 'Rèze'. 'Cascarolo Bianco' is much widespread in Piedmont (northern Italy), especially at the foot of the Alps where it was already mentioned by Croce (1606). The white 'Arvine Grande' is no longer cultivated in Valais where it is only kept in grape collections. It is supposed to be related to the more widespread 'Petite Arvine', but we found here that it is more related to 'Rèze' than to 'Petite Arvine' (data not shown). The blackberried 'Groppello di Revò' (also locally named 'Gropel', 'Gropel Nones') is only cultivated in the Non Valley in Trentino (northern Italy). It is genetically different from 'Groppello Gentile' and 'Groppello di Santo Stefano' grown in Lombardy (Costantini et al. 2001), contrary to Galet's (2000) opinion. 'Nosiola' is the only autochthonous white grape in Trentino, also locally named 'Groppello Bianco' or 'Nosellara', and it is also scarcely cultivated in Alto Adige under the name 'Spargelen'. Interestingly, both 'Nosiola' and 'Groppello di Revò' are traditionally considered putative descendants of Raetica. In grape parentages, when only two cultivars are involved in a parent-offspring relationship and the second parent is missing, the direction of the relationship (i.e. which is the parent and which is the offspring) cannot be inferred from molecular data. Thus, these four cultivars could be either parents or offspring of 'Rèze'. However, our data reject the possibility of a father-mother-progeny trio among these cultivars. Therefore, only one of them could theoretically be a parent of 'Rèze', the other ones being necessarily progenies of 'Rèze'. Given that 'Rèze' was mentioned much earlier than the other four cultivars, it is more likely that 'Rèze' could be their parent by way of four distinct crosses at different times and places (Table 3).

The remaining eight cultivars could be fullsiblings, second-degree (grandparent-grandoffspring, uncle-nephew or half-siblings) or more distant relatives of 'Rèze'. In order to assign these pairs to the most likely relationship category, we tested the likelihood ratios using full-sibling as primary hypothesis and second-degree relative as the next competing category. Only 'Rèze'-'Freisa' turned out to have likelihood ratio higher than 1 (Fig. 1), though with very low value (1.06). In 
Table 3 Grape cultivars closely related to 'Rèze', the most likely descendant of Raetica

Category of relationship to 'Rèze'

Parent-offspring

Cascarolo Bianco

Arvine Grande

Nosiola

Groppello di Revò
Second-degree relatives

Freisa

Cornalin du Valais

Roussin de Morgex

Petit Rouge

Four parent-offspring relationships were detected in Switzerland (Valais) and northern Italy (Piedmont and Trentino). As 'Rèze' was mentioned much earlier, we suppose that they are progenies of four distinct crosses between 'Rèze' and unknown cultivars. Furthermore, four second-degree relatives of 'Rèze' were found in Switzerland (Valais) and northern Italy (Piedmont and Aosta Valley)

other words, it is almost equally likely that 'Rèze' and 'Freisa' have these genotypes because they are full-siblings instead of second-degree relatives. This pair was therefore included in the likelihood ratio analysis using second-degree relatives as primary hypothesis and third-degree relatives as the next competing category. 'Freisa', 'Cornalin du Valais', 'Roussin de Morgex' and 'Petit Rouge' were supported as second-degree relatives of 'Rèze' (Table 3), with likelihood ratios ranging from 19.1 for 'Rèze'-'Freisa' to 3.33 for 'Rèze'-'Petit Rouge' (Fig. 1). 'Freisa' is an ancient cultivar from Piedmont where it was first mentioned in 1517 under the name fresearum (Nada Patrone 1987). 'Cornalin du Valais' is only cultivated in Valais, but Vouillamoz et al. (2003) showed that it is a progeny of 'Petit Rouge' and 'Mayolet' from the Aosta Valley. Moreover, 'Roussin de Morgex' from the Aosta Valley is most likely a progeny of 'Cornalin du Valais' and an unknown cultivar (Vouillamoz et al. in prep.). 'Cornalin d'Aoste', 'Mayolet' and 'Vuillermin' from the Aosta Valley as well as 'Goron' from Valais were almost equally likely either seconddegree or third-degree relatives of 'Rèze' (Fig. 1). This is consistent with the pedigree of Vouillamoz et al. (2003) showing that 'Cornalin d'Aoste' and 'Goron' are progenies of 'Cornalin du Valais', since the latter has a likely second-degree relationship with 'Rèze'. As mentioned by Blouin (2003) and verified in Vouillamoz and Grando (in press), likelihood ratios between competing categories reach some limitations above second-degree relatives, so that we did not analysed putative third-degree relatives of 'Rèze'.
Though formerly cultivated throughout Central Europe as table grapes, modern 'Veltliner' cultivars are now mainly restricted to eastern Austria. None of the four 'Veltliner' cultivars genotyped in Sefc et al. (1998) showed any possible relationship with 'Rèze'. Given their genetic diversity and their modern distribution, the 'Veltliner' group has not been investigated any further as putative descendant of Raetica. We also tested Berget's (1903) hypothesis that 'Rèze' could be a seedling of 'Prié' from the Aosta Valley. Our data rejected a parent-offspring relationship because 'Rèze' and 'Prié' had one allele in common at only 51 out of the 60 microsatellite loci analysed. However, they certainly are somehow related. Likelihood ratios analysis of these cultivars being second-degree relatives versus unrelated was very low (1.76), and the ratios of these cultivars being second-degree relatives versus third-degree relationship was even lower (0.47), so that it is equally likely that they have a second-degree or third-degree relationship.

\section{Conclusion}

Will we ever know the identity of Raetica? In this work we detected eight cultivars having parentoffspring or second-degree relatives relationship with 'Rèze', the most likely descendant of Raetica. Still, it is for now impossible to prove that 'Rèze' or any other cultivar actually is a descendant of Raetica. This might be achieved with ancient DNA analysis. Excavations from archaeological sites of the Roman period in the ancient land of the Raeti and surrounding areas yielded 
plenty of grape remains, mainly grape pips (see Ciurletti 1996 for Trentino-Alto Adige, Mermod 2005 for Valais). DNA extraction and amplification have already been successfully carried out at three microsatellite markers with grape pips from Hungary and France (Manen et al. 2003). Increasing the number of markers to at least six microsatellites would allow the comparison of archaeological grape remains with modern cultivars. We have tested Manen et al.'s method on grape pips dating form the Roman period excavated in Trento, northern Italy (G. Ciurletti personal communication) and in Gamsen, Valais (O. Mermod personal communication) but we were not able to amplify any microsatellite (data not shown), probably because of poor DNA conservation. In the future, other attempts with archaeological material from the Raetian regions should be tested and improved. If Raetian grape remains were proven to be close or identical to some modern cultivars, this would represent an invaluable and groundbreaking discovery for ancient history and viticulture.

Acknowledgements This research was partially funded by a consortium of wine producers in Trentino (Italy): Cantina d'Isera, Cantina Rotaliana di Mezzolombardo, Società Agricoltori Vallagarina, Cantina Sociale di Avio and Associazione Vino Santo Trentino. The authors would like to thank Gianni Ciurletti, Ufficio Beni Archeologici, Trento (Italy) and Olivier Mermod, Salgesch (Switzerland) for kindly providing us with some archaeological grape pips samples.

\section{References}

Aebischer P (1937) Les noms de trois cépages valaisans. Vox Roman 2:360-363

André J, Levadoux L (1964) La vigne et le vin des Allobroges. J Savants 169-181

Bauhin J (1650) Historia plantarum universalis. Ebroduni (Yverdon)

Berget A (1903) Etude ampélographique des vignobles du Léman, du Valais et du Val d'Aoste. Revue de Viticulture, Paris

Blouin MS (2003) DNA-based methods for pedigree reconstruction and kinship analysis in natural populations. Trends Ecol Evol 18(10):503-511

Bowers JE, Dangl GS, Vignani R, Meredith CP (1996) Isolation and characterization of new polymorphic simple sequence repeat loci in grape (Vitis vinifera L.). Genome 39(4):628-633
Bowers JE, Dangl GS, Meredith CP (1999) Development and characterization of additional microsatellite DNA markers for grape. Am J Enol Vitic 50(3):243246

Buchi E (1996) La vitivinicoltura cisalpina in età romana. In: Forni G, Scienza A (eds) 2500 anni di cultura della vite nell'ambito alpino e cisalpino. Istituto Trentino del Vino, Trento, pp 373-389

Ciurletti G (1996) La vitivinicoltura nel Trentino-Alto Adige fra preistoria ed età romana. In: Forni G, Scienza A (eds) 2500 anni di cultura della vite nell'ambito alpino e cisalpino. Istituto Trentino del Vino, Trento, pp 441-474

Costantini L, Roncador I, Grando MS (2001) Il caso Groppello della Val di Non chiarito con le analisi del DNA. L'Informatore Agrario 45:53-57

Crane GR (2005) Perseus digital library project. Tufts University, http://www.perseus.tufts.edu

Croce GB (1606) Della eccellenza e diversità dei vini, che nella montagna di Torino si fanno; e del modo di farli. P.A. Pizzamiglio, Torino

Desfayes M (2002) Noms dialectaux des végétaux du Valais romand. Bull Murithienne 120:57-111

Galet P (2000) Dictionnaire encyclopédique des cépages. Hachette, Paris

Goodnight KF, Queller DC (1999) Computer software for performing likelihood tests of pedigree relationship using genetic markers. Mol Ecol 8:1231-1234

Konovalov DA, Manning C, Henshaw MT (2004) KinGroup: a program for pedigree relationship reconstruction and kin group assignments using genetic markers. Mol Ecol Notes 4:779-782

Manen J-F, Bouby L, Dalnoki O, Marinval P, Turgay M, Schlumbaum A (2003) Microsatellites from archaeological Vitis vinifera seeds allow a tentative assignment of the geographical origin of ancient cultivars. J Archaeol Sci 30(6):721-729

Mermod O (2005) L'évolution de l'agriculture à travers les âges en Valais et en Suisse: bref survol. Bull Murithienne 122:49-54

Minch E, Ruiz-Linares A, Goldstein DB, Feldman M, Cavalli-Sforza LL (1995) Microsat (version 1.4d): a computer program for calculating various statistics on microsatellite allele data. University of Stanford, Stanford, California

Nada Patrone AM (1987) Bere vino in area pedemontana nel Medioevo. In: Il vino nell'economia e nella società italiana medioevale e moderna. Convegno di studi Greve in Chianti, pp 31-60

Pellerone FI, Edwards KJ, Thomas MR (2001) Grapevine microsatellite repeats: isolation, characterisation and use for genotyping of grape germplasm from Southern Italy. Vitis 40(4):179-186

Sefc KM, Steinkellner H, Gloessl J, Kampfer S, Regner F (1998) Reconstruction of a grapevine pedigree by microsatellite analysis. Theor Appl Genet 97(1-2): 227-231

Sefc KM, Regner F, Turetschek E, Glossl J, Steinkellner H (1999) Identification of microsatellite sequences in Vitis riparia and their applicability for genotyping of different Vitis species. Genome 42(3):367-373 
Sefc KM, Lefort F, Grando MS, Scott KD, Steinkellner H, Thomas MR (2001) Microsatellite markers for grapevine: a state of the art. In: Roubelakis-Angelakis KA (ed) Molecular biology and biotechnology of grapevine. Kluwer Academic Publishers, Amsterdam, pp 433-463

Tchernia A (1986) Le vin de l'Italie Romaine. Ecole française de Rome, Roma

This P, Jung A, Boccacci P, Borrego J, Botta R, Costantini L, Crespan M, Dangl GS, Eisenheld C, Ferreira Monteiro F, Grando MS, Ibanez J, Lacombe T, Laucou V, Magalhaes N, Meredith CP, Milani N, Peterlunger E, Regner, F, Zulini L, Maul E (2004) Development of a standard set of microsatellite reference alleles for identification of grape cultivars. Theor Appl Genet 109(7):1448-1458
Thomas MR, Scott NS (1993) Microsatellite repeats in grapevine reveal DNA polymorphisms when analysed as sequence-tagged sites (STSs). Theor Appl Genet 86(8):985-990

Thomas MR, Scott NS, Botta R, Kijas JMH (1998) Sequence-tagged site markers in grapevine and citrus. J Jpn Soc Hortic Sci 67(6):189-1192

Vouillamoz J, Maigre D, Meredith CP (2003) Microsatellite analysis of ancient alpine grape cultivars: pedigree reconstruction of Vitis vinifera L. 'Cornalin du Valais'. Theor Appl Genet 107(3):448-454

Vouillamoz JF, Grando MS (in press) Genealogy of wine grape cultivars: 'Pinot' is related to 'Syrah'. Heredity DOI: $10.1038 /$ sj.hdy.6800842 